NBER WORKING PAPER SERIES

\title{
FINANCIAL DEVELOPMENT AND GROWTH
}

IN THE SHORT AND LONG RUN

\author{
Raymond Fisman \\ Inessa Love \\ Working Paper 10236 \\ http://www.nber.org/papers/w10236
NATIONAL BUREAU OF ECONOMIC RESEARCH 1050 Massachusetts Avenue
Cambridge, MA 02138
January 2004

The views expressed herein are those of the authors and not necessarily those of the National Bureau of Economic Research.

(C2004 by Raymond Fisman and Inessa Love. All rights reserved. Short sections of text, not to exceed two paragraphs, may be quoted without explicit permission provided that full credit, including (C) notice, is given to the source. 
Financial Development and Growth in the Short and Long Run

Raymond Fisman and Inessa Love

NBER Working Paper No. 10236

January 2004

JEL No. G100, O150, O400

\begin{abstract}
We analyze the relationship between financial development and inter-industry resource allocation in the short- and long-run. We suggest that in the long-run, economies with high rates of financial development will devote relatively more resources to industries with a 'natural' reliance on outside finance due to a comparative advantage in these industries. By contrast, in the short-run we argue that financial development facilitates the reallocation of resources to industries with good growth opportunities, regardless of their reliance on outside finance. To test these predictions, we use a measure of industry-level 'technological' financial dependence based on the earlier work of Rajan and Zingales (1998), and develop new proxies for shocks to (short run) industry growth opportunities. We find differential effects of these measures on industry growth and composition in countries with different levels of financial development. We obtain results that are consistent with financially developed economies specializing in 'financially dependent' industries in the long-run, and allocating resources to industries with high growth opportunities in the short-run.

\author{
Raymond Fisman \\ Department of Economics \\ 823 Uris Hall \\ Columbia University \\ 3022 Boradway \\ and NBER \\ rf250@columbia.edu \\ Inessa Love \\ World Bank \\ 1818 H Street NW \\ Washington, DC 20433 \\ ilove@worldbank.org
}

New York, NY 10027
\end{abstract}


Economists have long been interested in the role of financial development in resource allocation. The hypothesis that financial development facilitates the efficient allocation of resources dates back to at least Schumpeter (1912), who conjectured that banks identify entrepreneurs with good growth prospects, and therefore help to reallocate resources to their most productive uses. More recently, Levine (1997) describes a number of channels through which financial development may affect allocative efficiency, including information generation, risk-sharing, financing, and monitoring. Rajan and Zingales (1998) point out that allocation may be differentially affected by industry characteristics: those that require a lot of upfront outside financing (relative to generated cash flow), such as drugs and pharmaceuticals (perhaps due to R\&D costs), will be less likely to grow in the presence of capital market imperfections than other industries where investment more closely coincides with cash generation. More recently, a number of other researchers have used a similar approach to look at the interaction of various 'fixed' industry characteristics and different aspects of financial development in predicting sectoral growth.

In this paper, we suggest that there is an important theoretical distinction in considering the role of financial development on industry growth in the short- and long-run that has heretofore gone largely unrecognized. In the short-run, we emphasize the role of financial institutions in reallocating resources to any industry that has experienced a positive shock to growth opportunities. We contrast this with a long-run view of the allocative effects of financial development, suggested by Rajan and Zingales (RZ), who argued that certain industries will naturally be more reliant on financial institutions to finance growth. Intuitively, this leads to separate predictions on the allocative effects of financial development in the short- and long-run. In the short-run, sectoral growth will be more correlated with growth opportunities in countries 
with well-developed financial institutions that allow firms to take advantage of these opportunities. In other words, in an economy with high financial development, actual industry growth in the short-run will be a function of growth opportunities (i.e. potential), regardless of inherent industry characteristics. In the long-run, financially dependent industries will have comparative advantage in countries with well-developed financial institutions and will thus capture a larger share of total production (relative to an economy with a low level of financial development), i.e., countries with high financial development will specialize in financially dependent industries. Thus, sector share of financially dependent industries will be higher in countries with high financial development.

In order to examine these contrasting predictions empirically, we require proxies for short-run shocks, as well as inherent industry reliance on financial intermediation. We develop measures of short-run shocks based on the assumption that there exist global shocks to growth opportunities that may be proxied for by actual growth in the United States. One interpretation of this measure is that it is a reflection of U.S. companies' optimal responses to worldwide shocks (such as oil shocks). Based on the assumption that if the U.S. has very well developed financial markets (as suggested by RZ), global shocks will be quickly reflected in actual growth rates in the United States. Under this assumption, actual industry growth in the US may be used as a proxy for growth opportunities for the same industry in other countries. Alternatively, we may think of these shocks as originating in the United States (due to demand and/or productivity shocks within the U.S.) and propagated to other countries with economic links with the United States. This interpretation allows for a further refinement of our measure of growth opportunities: We allow actual growth in the United States to differentially affect industries in different countries, based on their trade linkages to the United States. To implement this, we 
weight U.S. growth by the extent of trade with the United States for each industry in each country. Thus, our assumption of U.S.-based shocks allows us to generate a country-industry specific proxy for growth opportunities. This is in contrast to earlier work in this literature, which has always taken U.S.-based measures to apply uniformly around the world.

Our measure of underlying financial dependence builds on the earlier work of Rajan and Zingales (1998), which measures financial dependence as the mismatch between cashflow and investment, calculated using data on U.S. publicly traded firms. The rationale for this approach is that there are exist time-invariant, i.e. 'inherent' industry characteristics, which make some industries more (or less) reliant on external financing, and that this dependence will be reflected in U.S. firms, due to the efficiency of U.S. capital markets. Financially dependent industries will be at a comparative advantage in countries with well- developed financial markets that allow firms to take advantage of opportunities in industries with such characteristics, and will thus garner a larger share of production (which represents long-run accumulated growth rates) in these countries. This stands in contrast to the idea of shocks to growth opportunities that is based on temporary, i.e. time-specific, shocks which will be reflected in short-run growth.

Our results are broadly consistent with the arguments laid out above: industry sectoral growth is more correlated with our measures of industry shocks in countries with well-developed financial markets; industry sectoral shares are more correlated with financial dependence in countries with high financial development. Further, we find similar patterns for alternative measures of financial dependence, including R\&D intensity (Beck and Levine, 2002) and trade credit dependency (Fisman and Love, 2003).

Our results highlight the important distinction between the roles of financial development in resource allocation in the short- and long-run, and also provide some guidance and structure 
for future work in this area. In particular, we introduce a broader measure of 'growth opportunities' that we claim is more suited to studying allocation through sectoral growth, while intrinsic industry characteristics (such as financial dependence) should be more useful in predicting allocation of sector shares. Further, our paper suggests a reinterpretation and a potential augmentation to a number of earlier works that follow the methodology of Rajan and Zingales (1998). To cite just a few examples, Claessens and Laeven (2003) examine industryspecific tangibility of assets and its relationship to property rights protection; Fisman and Love (2003) study industry-specific trade credit affinity; and Cetorelli and Gambera (2003) analyze on the relationship between different aspects of financial development, 'external dependence,' and sectoral growth.

The rest of the paper is structured as follows: Section 1 gives a brief overview of the various mechanisms through which financial institutions may facilitate efficient resource allocation; Section 2 describes our empirical approach; our data are described in Section 3; In Section 4, we report our results; and in Section 5, we conclude.

\section{Theories of Financial Development and Resource Allocation}

While financial development may affect the level of economic growth through numerous channels, we focus here on the role of financial institutions in allocating resources to firms or industries with good growth opportunities. Even within this limited realm, there exists a vast body of work; we provide only a brief and limited overview to highlight the fact that there exist several functions of financial intermediaries that could have implications for both short- and long-run sectoral growth. ${ }^{1}$ These include the provision of external financing; information

\footnotetext{
${ }^{1}$ See Levine (1997) for an overview with greater breadth and depth.
} 
acquisition and dispersion; governance and oversight; and risk diversification. We briefly discuss each of these in turn, emphasizing the role of financial institutions in both the short- and long-run.

Provision of External Finance - As described by Schumpeter (1912), financial institutions provide funding to entrepreneurs with good growth prospects. Any industry with high growth opportunities will require a relatively large amount of outside financing, since future cash flow (and current investment) will be high relative to current cash flow. Since financial institutions allow firms (and hence industries) that have good growth opportunities to better finance current investment, industries with good growth opportunities should grow relatively more in countries with high financial development. In addition, as suggested by Rajan and Zingales (1998), there may be certain industries where there is a 'natural' lag between investment opportunities and cash flow. Industries with this inherent need for external finance (i.e. financially dependent industries) will be relatively advantaged in responding to growth opportunities at all times in countries with well-developed financial institutions, i.e., these countries will have a comparative advantage in finance-dependent sectors. These incremental relative advantages will accumulate over time. Hence, we anticipate that a relatively large share of output in high financial development economies will be in high external finance industries.

We further note that conversely, some industries may be naturally better suited to obtain external financing from sources other than formal financial intermediaries. One example is suggested by Fisman and Love (2003), which examines trade credit access and intersectoral allocation. Following their theoretical discussion, we suggest here that industries with ready trade credit access should be less reliant on formal financial institutions to finance growth 
opportunities, and should therefore be relatively well-represented in countries with low financial development.

Information Acquisition and Dispersion - In addition to the financing role described above, King and Levine (1993) emphasize the role of financial institutions in overcoming informational problems that are likely to loom large in areas with new and emerging opportunities. Through price signals and specialized resources devoted to evaluating firms' prospects, well-functioning financial institutions may both directly devote resources to promising ventures, and also signal high potential sectors to the broader economy. In addition to facilitating growth in any new and uncertain sector, therefore, this reasoning suggests that industries in which information is inherently difficult to acquire (such as high R\&D sectors, which we consider below) will obtain a relatively large share of output in high financial development economies.

Risk and Uncertainty - In addition to limited information, the financing of new opportunities is likely to be accompanied by risk. In the model of De la Fuente and Marin (1996), for example, this leads entrepreneurs to devote resources to safer but lower growth projects. This implies a weaker response to growth opportunities, and suggests that industries that are generally risky (once again, we will suggest high $\mathrm{R} \& \mathrm{D}$ sectors have this attribute) will be a relatively large share of production in high financial development economies.

Monitoring - The model of Blackburn and Hung (1998) focuses on the monitoring role of financial institutions in promoting growth. Closely related to their model is the idea that financial intermediaries may 'create winners' in addition to 'picking winners.' That is, in 
addition to choosing to finance projects that are expected to grow through the provision of funds, financial institutions may ensure that the firms that receive funding use their resources to best take advantage of growth opportunities. Furthermore, it is plausible that high R\&D industries (or intangible-intensive industries generally) are more likely to be subject to concerns of moral hazard.

\section{Empirical Approach}

\subsection{Industry Growth and Growth Opportunities}

In order to assess the responsiveness of resource allocation to growth opportunities, we first require a proxy for these opportunities. Our first identifying assumption is based on the premise that there exist global industry-specific shocks to growth opportunities i.e., some component of growth opportunities is common across countries.

These global shocks could arise as a consequence of technological innovations (for example, the invention of semiconductors or cellular phones) or global shifts in factor prices (for example oil shocks). Following the assertion of Rajan and Zingales (1998), we argue that because of its well-developed financial market institutions, the United States will be well-positioned to take advantage of these opportunities, so that $\mathrm{GO}^{*}{ }_{\text {ict }}=\mathrm{USGrowth}_{\mathrm{it}}+\varepsilon_{\mathrm{ict}}$, where $\mathrm{GO}^{*}$ ict are the (unobserved) growth opportunities in industry-country ic at time t. That is, growth opportunities include both global and idiosyncratic components, with actual USGrowth acting as our proxy for worldwide shocks to growth opportunities. Our test of whether financial development facilitates efficient responses to these shocks at time $t$ is then: 
(1) Growth $_{\text {ict }}=\alpha_{i}+\alpha_{c}+$ FD $_{\mathrm{c}} *$ USGrowth $_{\text {it }}+\varepsilon_{\text {ic }}$

Next, we extend this model by allowing a proxy for growth opportunities to reflect the idea that in addition to global shocks, there will be a U.S.-specific component (as described in the introduction) that will be transmitted to countries with close trade ties to the United States. More precisely, we define:

(2) USShock $_{\text {ict }}=$ USTrade $_{\text {ict }} *$ USGrowth $_{\text {it }}$

Where USTrade $i$ is the share of trade (imports + exports) between the United States and country $\mathrm{c}$ as a fraction of total output in industry $\mathrm{i}$ at time $\mathrm{t}$. USShock it $_{\mathrm{it}}$ thus allows for the possibility that growth shocks may originate in the United States (because of its large size), and be transmitted to countries that have relatively significant trade ties to the United States. Although this approach is still reliant on US-based measures, it is a step forward in allowing for the generation of country-industry specific proxies for growth opportunities. ${ }^{2}$

\subsection{Industry Share and 'inherent' needs for finance}

In contrast to the short-run relation between growth opportunities and financial development discussed above, we expect that underlying industry characteristics, such as inherent need for finance, will interact with financial development to affect sector shares, since sector shares are a result of accumulated past growth rates. That is, economies with well-developed financial

\footnotetext{
${ }^{2}$ Fisman and Love (2004) provide an alternative assumption for country-specific proxies for growth opportunities.
} 
institutions will specialize in industries that have an inherent reliance on outside financing. Following the suggestion of RZ, we assert that some firms are dependent on financial institutions because of an inherent mismatch between cash flows and investment, due to underlying technological characteristics. We use the measure of external financial dependence constructed by RZ, which we call USNeeds $s_{i}$ and conjecture that:

(3) Share $_{i \mathrm{c}}=\alpha_{\mathrm{i}}+\alpha_{\mathrm{c}}+\beta_{1} \mathrm{FD}_{\mathrm{c}} * \mathrm{USNeeds}_{\mathrm{i}}+\varepsilon_{\mathrm{ic}}$

where Share ${ }_{i c}$ is a share of industry $i$ in total manufacturing output of country c. The hypothesis that $\beta_{1}>0$ implies that industries where expenses cannot be matched to cash flows will be more prevalent in countries with high financial development because they will have a comparative advantage in these industries.

Note that there are complications in considering the effects of RZ's variable, USNeeds (as a measure of inherent financial dependence) on industry share and growth. This measure is constructed as the difference between investment expenditures and current cash flow. Therefore, it will simultaneously pick up the effects of growth opportunities that result in high current investment (GO), as well as the differences across industries in the extent to which expenditures to take advantage of these opportunities cannot be matched to generated cash flows (Dependence). ${ }^{3}$ Hence,

(4) Needs $_{i t}=f\left(G_{i t}\right.$, Dependence $\left._{i}\right)$

\footnotetext{
${ }^{3}$ This alludes to the broader issue of constructing measures of underlying inherent industry characteristics using data from a particular time period. We discuss this concern further in the data section below.
} 
The nature of $f($.$) will depend on underlying technologies, so we do not attempt to assign a$ functional form to this relationship. We simply make the observation that USNeeds will be correlated with our proxy for global growth opportunities, USGrowth, but will also reflect the differential ability of industries to rely on external finance due to the technological differences i.e. financial dependence. Thus, in our model, the interaction USNeeds*FD will be significant in predicting Growth $_{\text {ict}}$, if the analysis is done without controlling more directly for growth opportunities. This is the regression reported by Rajan and Zingales (1998). In other words, USGrowth is a purer reflection of growth opportunities, while USNeeds is a reflection of industry financing needs, which incorporates simultaneously elements of growth opportunities, financial dependence, and the form of $\mathrm{f}($.$) in (4) above. Thus, while USNeeds may be used as a$ time-varying predictor of financing industry needs, we suggest that our USGrowth measure is a more direct proxy for growth opportunities, as in (1) above. ${ }^{4}$ Hence, we suggest that when we include the USGrowth*FD interaction in addition to USNeeds*FD, this more direct measure of growth opportunities will dominate in the growth regression. This will not be the case in sectoral share regressions, where we expect the underlying industry characteristic of financial dependence to be the dominant explanatory factor. The main difference in our two approaches is the following: we argue that inherent needs for funds affect industry shares while RZ argued that they affect industry growth. In our model, growth is primary affected by temporary shocks to growth opportunities; the effect of underlying industry characteristics on sectoral growth is thirdorder.

\footnotetext{
${ }^{4}$ Our discussion on sector shares suggests that the interactive effect of growth opportunities and financial development on sectoral growth should be stronger in financially dependent industries. This is a third-order effect (i.e., a triple interaction). When we looked at the triple interactions of FD*USGrowth*Dependence, the coefficients were of the predicted signs, but were not generally significant.
} 
In summary, our approach provides sharply contrasting hypotheses regarding the importance of USGrowth and USNeeds in predicting industry growth versus predicting industry shares: USGrowth, as a proxy for growth opportunities, will dominate US Needs in predicting sectoral growth across countries, while USNeeds, as a proxy for external finance dependence, will dominate USGrowth in predicting sector shares.

Our claim regarding the relationship between underlying industry characteristics and sectoral allocation is a more general one, and will be applicable to any underlying feature of an industry that leads to greater (or lesser) reliance on (formal) financial markets. We therefore include two additional 'robustness' tests based on earlier work on financial markets and intersectoral allocation. First, we draw on the work of Beck and Levine (2002) who claim that R\&D intensity may also lead to a relatively high reliance on financial intermediaries. We predict a similar effect of R\&D intensity on sector shares as with USNeeds: R\&D intensive industries will be relatively well-represented in high financial development economies. Also, we examine the effect of trade credit availability, as suggested by Fisman and Love (2003), who argue that firms in industries with easy access to trade credit (i.e., high payables) will be able to finance growth with less need to access formal financial markets. Therefore, we predict an opposite effect: industries with higher 'trade credit afinity' will be relatively well-represented in countries with low financial development. Thus, we also run regressions of the form:

(5) Share $_{\mathrm{ic}}=\alpha_{\mathrm{i}}+\alpha_{\mathrm{c}}+\beta_{3} * \mathrm{FD}_{\mathrm{c}} * \mathrm{USR} \& \mathrm{D}_{\mathrm{i}}+\varepsilon_{\mathrm{ic}}$, where $\beta_{3}>0$

(6) Share $_{i c}=\alpha_{i}+\alpha_{c}+\beta_{4} * \mathrm{FD}_{\mathrm{c}} * \mathrm{USAPAY}_{\mathrm{i}}+\varepsilon_{\mathrm{ic}}$, where $\beta_{4}<0$ 
Where, $U S R \& D_{i}$ and USAPAY ${ }_{i}$ are industry-specific measures of R\&D intensity and trade credit affinity (measured by accounts payables over assets ratio) respectively.

\section{Data}

Our data are drawn primarily from Rajan and Zingales (1998), and described in detail in that paper. For comparison with their work, the main outcome variable is real growth in valued added, estimated for each of 37 industries in 42 countries over the period 1980-1990. The original data source is Industrial Statistics Yearbook published by United Nations (1993). We use the original measure of external financial dependence constructed by RZ, which we refer to as USNeeds to highlight the fact that this measure captures the need for external finance and that it is calculated using US data (obtained from the Compustat database). The original measure is calculated as a ratio of investment minus cash flow divided by investment and captures the percent of total investment that is financed by the external funds (see RZ for more details on calculation of this measure).

To construct our first measure of growth opportunities, USGrowth, we calculate industrymedian of real sales growth between 1980 and 1990 using all firms from Compustat. ${ }^{5}$ This industry-specific measure of growth opportunities assumes that there is some component of growth opportunities that is common across all countries - i.e. a global shock. Our second measure of growth opportunities, denoted by USShock, is USGrowth, adjusted for the trade flows. First, we construct USTrade, which equals to the ratio of (exports $s_{\mathrm{cj}}+$ imports $\left._{\mathrm{cj}}\right) /($ total output $_{\mathrm{cj}}$ ), where exports and imports measure trade of country c with the US in each industry $j$.

\footnotetext{
${ }^{5}$ We first calculate the real average growth rate for each firm in the sample for the decade of 1980's and then take the industry-level median of the firm-level averages of growth rates. We excluded $1 \%$ of the top and bottom tails of the distribution of firm-years of sales growth to eliminate cases of mergers, acquisitions, or disposals of assets. This parallels the approach used by RZ in calculating their external financial dependence measure.
} 
This measure captures the importance of trade with the US for each industry-country combinations. We obtain export and import data for each country-industry from Compatible Trade and Production Database, COMTAP, distributed by OECD and described in Harrigan (1996). The advantage of this trade data is that it uses the same industry classification as in the original RZ data (i.e. ISIC classification). We obtain total output data from the same Industrial Statistics database published by UN that was used by RZ to construct original industry growth measure. To reduce potential endogeneity, our trade measure is constructed for the year 1980 and it captures the trade at the beginning of the decade for which the growth data are constructed. Then, our second measure of country-industry specific growth opportunities, USShock, is constructed as a product of USGrowth*USTrade.

Two additional industry-level measures - R\&D intensity, USR\&D, and Trade Credit Affinity, USAPAYTA - are constructed from Compustat for the same sample of firms and same time-period as was used for original financial dependence measure. $R \& D$ intensity is measured as industry median of a ratio of $\mathrm{R} \& \mathrm{D}$ expenses (summed over the decade) over the total sales (again summed over the decade). USAPAYTA is measured as a ratio of accounts payable to total assets. It captures the industry's reliance on trade credit finance and is described in detail in Fisman and Love (2003).

Finally, we utilize RZ's primary measure of financial market development, given by the sum of market capitalization and total domestic credit provided by banks to private borrowers, referred to as "Total capitalization". ${ }^{6}$ A complete list of the variables used in this paper with the

\footnotetext{
${ }^{6}$ Note that we recognize the potential endogeneity of financial development. However, it is not clear that appropriate instruments exist for this variable. When we use the set of instruments that are commonly used in this literature, legal origin and settler mortality (see, for example, Beck et al, 2004), we obtain results that are statistically significant at the ten percent level in both our share and growth regressions, and consistent with those reported below. However, it is not clear that these variables satisfy the conditions required of instruments, so we do not report those results in our tables. These results are all available from the authors.
} 
original sources is given in Table 1; Table 2 Panel A shows the basic summary statistics for all measures used in the paper and Panel B reports industry-level measures. We note that the correlation of USgrowth and USNeeds is 0.65 , (significant at $1 \%$ ) which is in line with our hypothesis that they are both related to growth opportunities. On the other side, the correlation of USR\&D and USNeeds is even higher, at 0.78 , which is at least suggestive of the possibility that they may both be capturing an industry-specific measure of financial dependence.

As a final observation, we note that we have generated both our time-varying measure of growth shocks, as well as our industry characteristic variables that should not be susceptible to the time period chosen. We will therefore follow RZ by generating our industry variables using data from the 1970s as well, to make sure that our sector share results are not sensitive to choice of decade for the generation of our time-invariant characteristics. We will also examine the relationship between growth in the 1980's and our measures of shocks, derived from 1970's Compustat data. Our 'time invariant' measure of financial dependence should still predict sector shares, while our 'non-event window' growth data should not be predictive of 1980's growth. We therefore define the variables USNeeds70, USGrowth70, and USShock70 that are generated precisely as described above, using data from 1970-80. It is interesting to note that the correlation between USGrowth and USGrowth 70 is 0.10 , while the correlation between USNeeds and USNeeds70 is 0.63 . This lends some credence to the proposition that USNeeds variable represents 'structural' characteristics, while USGrowth represents a temporal characteristic.

\section{Results}

\subsection{Financial Development and (Short-Run) Growth}


We begin by examining the hypothesis that financial development helps to channel resources to industries with good growth opportunities. These results, based on equation (1) above, are reported in Table 3, column (1). We find that the coefficient on USGrowth*FD takes on the value 1.07 , and is significant at the 1 percent level. Its magnitude implies that an improvement in financial development from 0.46 (Philippines, the $25^{\text {th }}$ percentile) to 0.98 (Italy, the $75^{\text {th }}$ percentile) will result in an increased responsiveness to global growth shocks of 0.56 . In column (2), we replicate the results of Rajan and Zingales (1998), which shows that USNeeds*FD is a significant predictor of growth in a regression where we have not directly controlled for growth shocks. In column (3), we report results with both USNeeds*FD and USGrowth*FD as regressors. Consistent with our hypothesis that USNeeds is a weaker proxy for global growth prospects, we find that when both USNeeds and USGrowth are included in the same regression, the USNeeds interaction is no longer significant. ${ }^{7}$ In columns (4) and (5) we use our measure of industry-country specific growth opportunities, USShock. We find that the interaction term USShock*FD is significant at a higher level than the USGrowth interactions reported in (1) and (3). However, the coefficient on USShock*FD implies a considerably smaller effect of financial development on resource allocation, since the standard deviation of USShock is about a tenth of that of USGrowth, while its coefficient is only four times greater. This is consistent with USShock picking up only a part of global shocks (relative to USGrowth), but measuring this component of shocks more precisely. We note finally that USNeeds is again is not significant in model (5) at conventional levels.

\footnotetext{
${ }^{7}$ We examined the sensitivity of these results to outliers in growth rates first by dropping the top and bottom one percent of observations of Growth and second by employing a robust regression approach. In both cases the coefficient on USNeeds*FD was not significant, while USGrowth*FD remained significant at the one percent level. These results are available from the authors.
} 
We next consider the possibility that financial development may be proxying for other country-level characteristics that create US-specific correlations in sectoral growth. First, we consider the possibility that USGrowth may be a better proxy for growth opportunities in wealthier economies. Since financial development is correlated with income, our interaction term USGrowth*FD may be picking up this wealth effect. This was recognized by RZ, with reference to the theory of Dornbush, Fisher and Samuelson (1977), which finds that as technologies mature, industries involving those technologies migrate from developed to developing countries. Therefore, in columns (5) - (6) of Table 3, we include the interactions USGrowth* $\log$ (GDP per capita) and USShock* $\log$ (GDP per capita). The coefficients on our two interaction, USGrowth*FD and USShock*FD, remain significant at the 1 percent level in both regressions. Second, we allow for the possibility that the level of human capital development may affect growth in industries that require highly skilled workers. If growth shocks during the 1980's were in such industries, then the interaction with of USGrowth (or USShock) and financial development could be picking up human capital effects. We use a commonly utilized measure of human capital, average years of schooling in 1980, and find that in columns (8) and (9) our main results remain robust to adding these controls. As a final specification check, in columns (10) and (11) we repeat our basic specification using Compustat data from the 1970's. In column (10), we find that the interaction USGrowth70*FD is marginally significant $(t=1.74)$. Note, however, that unlike our 1980's interaction, this effect is highly unstable, and may be an artifact of the moderate correlation of USGrowth and USGrowth70: Removal of outliers, adding basic controls, or adding the USGrowth*FD interaction, all cause this effect to evaporate. In column (11), we find that the interaction USShock*FD is not significant. 


\subsection{Financial Development and Sector Share}

We now examine the relationship between fixed industry characteristics and sector share. In Table 4, column (1), we report results based on equation (2). Consistent with the hypothesis that countries with well-developed financial institutions specialize in industries that require high rates of external finance, the coefficient on USNeeds*FD is significant at the 1 percent level. Its magnitude, 0.015 , suggests an even larger allocative role for financial development than the growth regressions described previously, since the standard deviation of Share ${ }_{\mathrm{ic}}$ is about 20 percent of that of Growth ${ }_{i c}$. To ensure that this result is not simply the result of correlated growth shocks, we include USGrowth*FD as a control in column (2). The coefficient on this interaction term is not significant, and has very little effect on the coefficient on USNeeds*FD. Thus, while our flow measure, USGrowth, has a significant impact on changes in allocations (i.e., Growth $_{i c}$ ), it is not a significant predictor of shares in allocation (i.e., Share ${ }_{\text {ic }}$ ). As additional controls, we include USNeeds* $\log$ (GDP per capita) and USNeeds* Human capital in columns (4) and (5). The first is to account for the possibility that countries at similar levels of economic development will specialize in similar sectors (see, for example, Chenery, 1960). The second interaction allows for the possibility that industries with inherent needs for external funds may also have high needs for skilled labor; since human capital development is correlated with financial development (Table 2), our interaction could be picking up this effect. The original interaction term USNeeds*FD remains significant in both cases. Finally, we use USNeeds $70 *$ FD to examine the sensitivity of our results to the choice of time period; in contrast 
to the growth results above, we find that USNeeds70 implies an even larger effect on sector share than USNeeds, though we cannot reject the hypothesis that the effect is the same.

In columns (8) and (9), we show results for two alternative measures of financial intermediary dependence: accounts payable intensity, and R\&D intensity. Column (8) uses the measure of reliance on trade credit finance proposed by Fisman and Love (2003). Consistent with the hypothesis laid out in this earlier work, we find that industries that are able to rely more on trade credit finance attain a larger share of production in countries with less-developed financial markets, due to a comparative advantage in these industries. We obtain significance at only the $7 \%$ level. Trade credit remains a significant predictor of sector shares when USNeeds*FD and/or USAPAY*GDPPC are included as controls. Column (3) shows R\&D intensity as a final measure external finance dependence, as suggested in Section 1. The coefficient on USR\&D*FD is significant at one percent, and its size implies a similar effect as that of USNeeds. Note, however, that this result is unstable: the inclusion of both USNeeds*FD and USR\&D*FD in the same regression causes the R\&D interaction to lose significance. This may be because the two variables are proxying for similar industry characteristics: To a large degree our R\&D may be picking up the fact that research and development requires upfront investments, as suggested by the very high correlation between USNeeds and USR\&D.

\section{Conclusions}

In this paper, we point out an important distinction between the long- and short-run effects of financial market development. We emphasize that in the short-run, financial development will facilitate the reallocation of resources to any industry with high growth potential. Empirically, we find that actual growth is more highly correlated with our measure of 
growth opportunities in economies with high financial development. One important spin-off of our research is that in order to test this implication, we develop a plausible proxy for industrycountry growth shocks. In the long-run, we emphasize the implications of financial development for the types of sectors that come to dominate economic activity: Countries with high financial development specialize in industries with an inherent reliance on external finance. We believe that this work will help to guide future work examining the role of financial development, and allocative institutions more broadly defined, in the development process. 


\section{References}

Beck, Thorsten, Asli Demirguc-Kunt and Ross Levine, 2004, "Law, Endowments and Finance", Journal of Financial Economics, Forthcoming.

Beck, Thorsten and Ross Levine, 2002, "Industry Growth and Capital Allocation: Does having a Market- or Bank-based System Matter?” Journal of Financial Economics, 64, pp.147-180.

Blackburn, Keith and Victor Hung, 1998, "A Theory of Growth, Financial Development and Trade," Economica, v.65, n.257, pp107-24.

Cetorelli, Nicola and Michele Gamberra, 2001, "Banking Market Structure, Financial Dependence and Growth: International Evidence from Industry data," Journal of Finance, vol.56, no2, pp. 617-648.

Chenery, Hollis, 1960, "Patterns of Industrial Growth," American Economic Review, Vol. 50 (4), pp. 624-654.

Claessens, Stijn, and Luc Laeven, "Financial Development, Property Rights, and Growth", Journal of Finance, Forthcoming, December 2003.

De la Fuente, Angel and Jose Maria Marin, 1996, "Innovations, Bank Monitoring and Endogenous Financial Development," Journal of Monetary Economics, v.38, n.2, pp. 269-301.

Dornbush, Rudiger, Stanley Fisher and Paul A. Samuelson, 1977, "Comparative Advantage, Trade and Payments in a Ricardian Model with a Continuum of Goods." American Economic Review, 67(5), pp.823-39.

Fisman, Raymond and Inesssa Love, 2003, "Trade Credit, Financial Intermediary Development and Industry Growth," Journal of Finance xx , pp. xx.

Fisman, Raymond and Inesssa Love, 2004, "Financial Development and Intersectoral Allocation: A New Approach," Journal of Finance, forthcoming.

Harrigan, James, 1996, "Openness to Trade in Manufactures in the OECD", Journal of International Economics, 40(1/2), February, 23-40.

King, R.G. and R. Levine, 1993, "Finance and Growth: Schumpeter Might be Right," Quarterly Journal of Economics, 108(3), pp. 717-37.

Levine, Ross, 1997, Financial Development and Economic Growth, Journal of Economic Literature, vol 35, pp. 688-726.

Rajan, R., and L. Zingales, 1998, Financial Dependence and Growth, American Economic Review 88(3), 559-86. 
Schumpeter, J.A., orig. 1912, The Theory of Economic Development, trans. 1934 (Harvard U.P., Cambridge, MA).

United Nations, 1993, Statistical Division, Industrial Statistics Yearbook, Vol. 1 New York: United Nations. 


\section{Table 1. Variable Definitions and Sources.}

Abbreviation Description

Industry-level variables (based on US data).

USNeeds Dependence on external financing, industry-level median of the ratio of capital expenditures minus cash flow over capital expenditures (the numerator and denominator are summed over all years for each firm before dividing) for US. This variable measures the portion of capital expenditures not financed by internally generated cash. From Rajan and Zingales (1998).

USGrowth Growth in real sales, industry-level median of firm average growth rages over 1980-1990 for US firms, from Compustat.

USAPAYTA Industry-median of ratio of accounts payables over total assets calculated for all firms in Compustat (from Fisman and Love (2003).

USR\&D Research and Development intensity, calculated as industry median of R\&D to sales ratios (both are summed over the decade of 1980 before taking a ratio) calculated for all firms in Compustat.

\section{Country-Industry level variables:}

Industry growth $\quad$ Annual compounded growth rate in real value added estimated for the period 1980-1990 for each ISIC industry in each country from Rajan and Zingales (1998).

Fraction

USTrade

Industry's share of total value added in manufacturing in 1980 from Rajan and Zingales (1998).

Share of trade with the US as a fraction of total output in each industry and country in 1980 defined as (exports+Imports)/total output. Exports and Imports come from Compatible Trade and Production Database, COMTAP, distributed by OECD and described in Harrigan (1996). Total output comes from UNIDO - Industrial Statistics published by UN.

USShock

Defined as USGrowth*USTrade, a proxy for growth opportunities assuming a shock originating in the US and transmitted to each industry-country via trade linkages.

Country-level variables:

FD

Log GDP PC

Human
Financial Development, equal to the sum of Domestic Credit and Market Capitalization to GDP. Both are measured in 1980 and come from Rajan and Zingales (1998). Original source is International Financial Statistics (IFS).

Log of GDP per capita in US dollars in 1980. IFS

Human capital, equal to the average years of schooling from Rajan and Zingales (1998). 


\section{Table 2. Summary Statistics}

See Table 1 for variable definitions and sources.

Panel A. Descriptive Statistics and Correlations

\begin{tabular}{lllllll}
\hline \hline & & & & & \multicolumn{2}{c}{ Correlation with: } \\
\cline { 6 - 7 } & Mean & Median & St. Deviation & USNeeds USGrowth USAPAYTA \\
\hline Industry-Level Variables: & & & & & & \\
USNeeds & 0.313 & 0.226 & 0.397 & 1 & & \\
USGrowth & 0.041 & 0.038 & 0.030 & $0.64^{* * *}$ & 1 & \\
USAPAYTA & 0.090 & 0.089 & 0.018 & $-0.10^{* * *}$ & $-0.18^{* * *}$ & 1 \\
USR\&D & 0.022 & 0.014 & 0.022 & $0.78^{* * *}$ & $0.62^{* * *}$ & $-0.34 * * *$ \\
& & & & & & \\
\hline
\end{tabular}

Country-Industry level variables:

\begin{tabular}{lllllll} 
& & & & \multicolumn{3}{c}{ Correlation with: } \\
\cline { 6 - 7 } & Mean & Median & St. Deviation & Growth & Fraction & USTrade \\
Frowth & 0.033 & 0.029 & 0.101 & 1 & & \\
Fraction & 0.016 & 0.009 & 0.021 & $-0.13^{* * *}$ & 1 & \\
USTrade & 0.018 & 0.004 & 0.054 & 0.04 & $-0.09^{* * *}$ & 1 \\
USShock & 0.0007 & 0.0001 & 0.0027 & 0.04 & $-0.09^{* * *}$ & $0.91^{* * *}$ \\
\hline
\end{tabular}

Country-Level Variables:

\begin{tabular}{llllll} 
& & & & \multicolumn{2}{c}{ Correlation with: } \\
\cline { 5 - 6 } & Mean & Median & St. Deviation & FD & GDPPC \\
GDPPC & 0.712 & 0.654 & 0.366 & 1 & \\
Human & 7.818 & 7.883 & 1.336 & $0.44^{* * *}$ & 1 \\
\hline \hline
\end{tabular}


Panel B. Industry-Level Variables

\begin{tabular}{llrrrr}
\hline \hline & & & & & \\
ISIC code & Industry Description & USNeeds & USGrowth & USAPAYTA USR $\&$ D \\
\hline 311 & Food products & 0.137 & 0.036 & 0.114 & 0.005 \\
313 & Beverages & 0.077 & 0.037 & 0.090 & 0.009 \\
314 & Tobacco & -0.451 & 0.031 & 0.066 & 0.004 \\
321 & Textile & 0.400 & 0.043 & 0.102 & 0.008 \\
322 & Apparel & 0.029 & 0.027 & 0.111 & 0.003 \\
323 & Leather & -0.140 & 0.024 & 0.055 & 0.022 \\
324 & Footwear & -0.078 & 0.016 & 0.093 & 0.011 \\
331 & Wood Products & 0.284 & 0.031 & 0.088 & 0.007 \\
332 & Furniture & 0.236 & 0.044 & 0.092 & 0.008 \\
341 & Paper and Products & 0.176 & 0.037 & 0.082 & 0.014 \\
342 & Printing and Publishing & 0.204 & 0.065 & 0.076 & 0.009 \\
352 & Chemicals & 0.219 & 0.056 & 0.098 & 0.022 \\
353 & Petroleum refineries & 0.042 & -0.035 & 0.117 & 0.005 \\
354 & Petroleum and coal products & 0.334 & 0.002 & 0.098 & 0.006 \\
355 & Rubber products & 0.226 & 0.022 & 0.089 & 0.020 \\
356 & Plastic products & 1.140 & 0.088 & 0.102 & 0.021 \\
361 & Pottery & -0.146 & 0.073 & 0.067 & 0.024 \\
362 & Glass & 0.528 & 0.035 & 0.089 & 0.012 \\
369 & Non metal products & 0.062 & -0.001 & 0.065 & 0.015 \\
371 & Iron and Steel & 0.087 & -0.002 & 0.093 & 0.007 \\
372 & Non-ferrous metal & 0.005 & -0.017 & 0.078 & 0.010 \\
381 & Metal products & 0.237 & 0.039 & 0.089 & 0.011 \\
382 & Machinery & 0.445 & 0.033 & 0.087 & 0.021 \\
383 & Electric machinery & 0.767 & 0.068 & 0.084 & 0.040 \\
384 & Transportation equipment & 0.307 & 0.057 & 0.105 & 0.023 \\
385 & Professional goods & 0.961 & 0.064 & 0.075 & 0.068 \\
390 & Other ind. & 0.470 & 0.067 & 0.091 & 0.018 \\
3211 & Spinning & -0.088 & 0.028 & 0.149 & 0.011 \\
3411 & Pulp, paper & 0.151 & 0.061 & 0.065 & 0.008 \\
3511 & Basic chemicals excl. Fertil. & 0.253 & 0.038 & 0.083 & 0.031 \\
3513 & Synthetic resins & 0.159 & 0.047 & 0.092 & 0.032 \\
3522 & Drugs & 1.492 & 0.084 & 0.056 & 0.103 \\
3825 & Office, computing & 1.060 & 0.123 & 0.087 & 0.083 \\
3832 & Radio & 1.039 & 0.082 & 0.079 & 0.057 \\
3841 & Ship & 0.458 & 0.057 & 0.103 & 0.030 \\
3843 & Motor veichle & 0.389 & 0.048 & 0.114 & 0.018 \\
\hline \hline & & & & &
\end{tabular}


Table 3. Industry Growth, Growth Opportunities and Financial Dependence

Dependent variable is real growth in value added for each industry and each country. See Table 1 for Variable Definitions and Sources. All regressions include industry and country dummies. Heteroskedasticity robust standard errors appear in parenthesis. Significance levels $* * *, * *$ and $*$ correspond to $1 \%, 5 \%$ and $10 \%$ respectively.

\begin{tabular}{|c|c|c|c|c|c|c|c|c|c|c|c|}
\hline & $(1)$ & (2) & (3) & (4) & (5) & $(6)$ & $(7)$ & $(8)$ & $(9)$ & $(10)$ & $(11)$ \\
\hline \multirow[t]{2}{*}{ Fraction } & -0.905 & -0.912 & -0.923 & -0.797 & -0.828 & -0.925 & -0.817 & -0.944 & -0.804 & -0.866 & -0.816 \\
\hline & $(0.243)^{* * *}$ & $(0.246)^{* * *}$ & $(0.245)^{* * *}$ & $(0.305)^{* * *}$ & $(0.306)^{* * *}$ & $(0.243)^{* * *}$ & $(0.304)^{* * *}$ & $(0.256)^{* * *}$ & $(0.307)^{* * *}$ & $(0.251)^{* * *}$ & $(0.303)^{* * *}$ \\
\hline \multirow[t]{2}{*}{ USNeeds*FD } & & 0.069 & 0.033 & & 0.032 & & & & & & \\
\hline & & $(0.023)^{* * *}$ & $(0.028)$ & & $(0.021)$ & & & & & & \\
\hline \multirow[t]{2}{*}{ USGrowth*FD } & 1.069 & & 0.775 & & & 0.712 & & 0.951 & & & \\
\hline & $(0.351)^{* * *}$ & & $(0.427)^{*}$ & & & $(0.292)^{* *}$ & & $(0.320)^{* * *}$ & & & \\
\hline \multirow[t]{2}{*}{ USShock*FD } & & & & 4.386 & 4.031 & & 10.058 & & 7.046 & & \\
\hline & & & & $(1.226)^{* * *}$ & $(1.231)^{* * *}$ & & $(2.472)^{* * *}$ & & $(1.692)^{* * *}$ & & \\
\hline \multirow[t]{2}{*}{ USGrowth*GDPPC } & & & & & & 0.223 & & & & & \\
\hline & & & & & & $(0.113)^{* *}$ & & & & & \\
\hline \multirow[t]{2}{*}{ USShock*GDPPC } & & & & & & & -0.624 & & & & \\
\hline & & & & & & & $(0.240)^{* * *}$ & & & & \\
\hline \multirow[t]{2}{*}{ USGrowth*Human } & & & & & & & & 0.06 & & & \\
\hline & & & & & & & & $(0.04)$ & & & \\
\hline \multirow[t]{2}{*}{ USShock*Human } & & & & & & & & & -0.448 & & \\
\hline & & & & & & & & & $(0.210)^{* *}$ & & \\
\hline \multirow[t]{2}{*}{ USGrowth70*FD } & & & & & & & & & & 0.634 & \\
\hline & & & & & & & & & & $(0.364)^{*}$ & \\
\hline \multirow[t]{2}{*}{ USShock70*FD } & & & & & & & & & & & 0.973 \\
\hline & & & & & & & & & & & $(2.10)$ \\
\hline Observations & 1217 & 1217 & 1217 & 851 & 851 & 1217 & 851 & 1171 & 825 & 1217 & 851 \\
\hline R-squared & 0.29 & 0.29 & 0.29 & 0.38 & 0.39 & 0.3 & 0.39 & 0.29 & 0.37 & 0.28 & 0.38 \\
\hline
\end{tabular}




\section{Table 4. Industry Share, Growth Opportunities and Financial Dependence}

Dependent variable is Fraction (i.e. Industry's share of total value added in manufacturing in 1980 from Rajan and Zingales (1998)). See Table 1 for Variable Definitions and Sources. All regressions include industry and country dummies. Heteroskedasticity robust standard errors appear in parenthesis. Significance levels $* * *, * *$ and $*$ correspond to $1 \%, 5 \%$ and $10 \%$ respectively.

\begin{tabular}{|c|c|c|c|c|c|c|c|c|c|}
\hline & (1) & (2) & (3) & (4) & (5) & (6) & (7) & (8) & (9) \\
\hline USNeeds*FD & $\begin{array}{l}0.015 \\
(0.004)^{* * *}\end{array}$ & & $\begin{array}{l}0.014 \\
(0.005)^{* * *}\end{array}$ & $\begin{array}{l}0.011 \\
(0.005)^{* *}\end{array}$ & $\begin{array}{l}0.014 \\
(0.004)^{* * *}\end{array}$ & & & & \\
\hline USGrowth*FD & & $\begin{array}{l}0.154 \\
(0.049) * * *\end{array}$ & $\begin{array}{l}0.029 \\
(0.056)\end{array}$ & & & & & & \\
\hline USNeeds*GDPPC & & & & $\begin{array}{l}0.003 \\
(0.001)^{* *}\end{array}$ & & & & & \\
\hline USNeeds*Human & & & & & $\begin{array}{l}0.0006 \\
(0.0004)\end{array}$ & & & & \\
\hline USNeeds70*FD & & & & & & $\begin{array}{l}0.036 \\
(0.008)^{* * *}\end{array}$ & $\begin{array}{l}0.031 \\
(0.007)^{* * *}\end{array}$ & & \\
\hline USGrowth70*FD & & & & & & & $\begin{array}{l}0.077 \\
(0.065)\end{array}$ & & \\
\hline USUSAPAYTA*FD & & & & & & & & $\begin{array}{l}-0.151 \\
(0.079)^{*}\end{array}$ & \\
\hline USR\&D*FD & & & & & & & & & $\begin{array}{l}0.254 \\
(0.079)^{* * *}\end{array}$ \\
\hline Observations & 1306 & 1306 & 1306 & 1306 & 1258 & 1267 & 1267 & 1306 & 1306 \\
\hline R-squared & 0.47 & 0.46 & 0.47 & 0.47 & 0.47 & 0.47 & 0.47 & 0.47 & 0.47 \\
\hline
\end{tabular}

